\title{
JUSTICIABELEN: PENEGAKAN HUKUM DI INSTITUSI PENGADILAN DALAM MENGHADAPI PANDEMI COVID-19
}

\author{
Azis Ahmad Sodik \\ Advokat dan Konsultan Hukum pada Perhimpunan Advokat Indonesia \\ Email: azisahmads@gmail.com
}

\begin{abstract}
The Epidemic of Covid-19 which has hit Indonesia has a very worrying impact, not only in the socioeconomic sector, but also affects to all sectors, including the structure of the justice system in Indonesia. The policy of Government in dealing with this pandemic is the implementation of Large-Scale Social Restrictions as regulated in Government Regulation No. 21 of 2020 concerning Large-Scale Social Restrictions. This is one of the efforts to reduce the spread rate of covid-19. This is a big challenge for the holding of justice, especially for justice seekers who need legal certainty, because if it continues, there is a risk of contracting the Covid-19 virus, whereas if the trial is postponed, it will result in losses for the community of justice seekers (justiciabelen), because of their status and their fate is still unclear. This study aims to find out how law enforcement in court institutions during a pandemic. The method for this research is normative juridical analysis, Qualitative approach and literature study. From this research, it is known that in efforts to enforce law in a court in a pandemic situation it must meet at least 5 (five) factors: (1) Legal Instrument Factors, (2) Law Enforcement Factors, (3) Facilities Factors, (4) Community Social Factors (5) Cultural Factors.
\end{abstract}

Keywords: Covid-19, Judicial System, Justiciabelen, Law Enforcement

\begin{abstract}
ABSTRAK
Wabah covid-19 yang telah melanda Indonesia, telah memberi dampak yang sangat mengkhawatirkan, tidak hanya pada sektor sosial ekonomi saja, tetapi juga berdampak pada seluruh sektor, termasuk pada tatanan sistem peradilan di Indonesia. Kebijakan pemerintah dalam megahadapi pandemi ini yaitu dengan diberlakukannya Pembatasan Sosial Berskala Besar (PSBB) seperti diatur dalam Peraturan Pemerintah Nomor 21 Tahun 2020 tentang Pembatasan Sosial Berskala Besar, kebijakan ini merupakan salahsatu upaya untuk menekan angka penyebaran dari covid-19. Hal ini menjadi tantangan besar bagi terselengaranya peradilan, terutama bagi para pencari keadilan yang membutuhkan kepastian hukum, karena apabila persidangan tetap dilaksanakan, maka beresiko terdampak virus Covid-19, sedangkan apabila persidangan ditunda, maka mengakibatkan kerugian bagi masyarakat para pencari keadilan (justiciabelen), karena status dan nasib mereka masih belum diputuskan. Penelitian ini bertujuan untuk mengetahui bagaimana penegakan hukum di institusi pengadilan pada saat pandemi. Metode untuk membahas penelitian ini, yaitu dengan menggunakan pendekatan yuridis normatif dan kualitatif serta data di peroleh dengan studi kepustakaan. Dari penelitian ini diketahui bahwa dalam upaya penegakan hukum di pengadilan dalam keadaan pandemi ini setidaknya harus memenuhi 5 (lima) faktor: (1) Faktor Instrumen Hukum, (2) Faktor Penegak Hukum, (3) Faktor Sarana serta Fasilitas, (4) Faktor Sosial Masyarakat (5) Faktor Kebudayaan.
\end{abstract}

Kata Kunci: Covid-19, Justiciabelen, Penegakan Hukum, Sistem Peradilan

* Copyright (c) 2020 Azis Ahmad Sodik

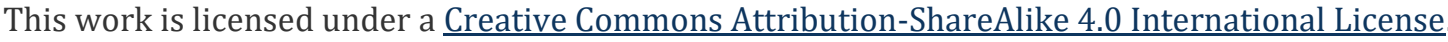




\section{PENDAHULUAN}

Kondisi penyebaran dari virus covid-19 sudah sangat mengkhawatirkan. Di Indonesia sendiri terhitung sejak tanggal 12 Mei 2020, Pukul 20.51 WIB data yang sudah terkonfirmasi positif sebanyak 14.749 orang (Gugus Tugas Percepatan Penangana COVID-19, 2020), artinya virus ini sudah memasuki tahap darurat, dan angka kematiannya setiap hari terus meningkat dan hal ini berdampak pada seluruh aspek, baik aspek sosial, politik, budaya, ekonomi, keamanan, pertahanan, kesejahteraan, bahkan tak terkecuali berdampak pada tatanan sistem peradilan di Indonesia.

Pada 30 Maret 2020 media mainstream telah memberitakan, bahwa dalam upaya menghadapi pandemi yang disebabkan oleh covid-19 ini, Presiden akan menggunakan Perppu Tentang Darurat Sipil (Danu, 2020). Hal Ini merujuk kepada Perppu No 23 tahun 1959. Namun hal tersebut menimbulkan respon yang beragam dari berbagai kalangan masyarakat, sebagian dari masyarakat mengatakan agar dalam menangani pandemik ini pemerintah menjalankan Undang-Undang Republik Indonesia Tentang Kekarantinaan Kesehatan (Lembaran Negara Repulik Indonesia Tahun 2018, No 128), yang ditandatangani oleh Presiden Joko Widodo pada 7 Agustus 2018, sebagian dari masyarakat tidak menerima Perppu tersebut karena dinilai Perppu tersebut kurang tepat untuk penangan covid-19 ini karena karena latar belakang dari perppu tersebut adalah Perppu yang menjelaskan mengenai kondisi dalam Keadaan Bahaya (Handayanto \& Herlawati, 2020).

Pada pekan terakhir dibulan maret, tertanggal 31 Maret 2020, Presiden Jokowi terbitkan Peraturan Pemerintah Nomor 21 Tahun 2020 yang mengatur tentang pemberlakuan Pembatasan Sosial Berskala Besar (PSBB). Peraturan ini diharapkan dapat mengurangi resiko terdampak penularan virus Covid-19 atau bahkan dapat memutus rantai penyebaran, serta diharapkan dapat mengurangi pengurangan kerumunan massa dalam satu tempat, termasuk dalam hal ini adalah pelaksanaan persidangan di pengadilan yang dilakukan secara langsung.

Adanya adagium fiat justitia ruat coelum (keadilan tetap ditegakan meski langit runtuh) menjadi salahsatu dasar penegakan hukum bagi masyarakat pada masa pandemi covid-19 ini. Namun masalah mulai muncul sejalan dengan diberlakukannya Pembatasan Sosial Berskala Besar (PSBB), apakah pemenuhan hak-hak terhadap para pencari keadilan dapat terpenuhi? Sedangkan apabila persidangan tetap dilaksanakan seperti biasa akan sangat beresiko terhadap penyebaran Covid-19, sedangkan apabila persidangan ditunda akan mengakibatkan kerugian terhadap hak-hak para pencari keadilan, karena status serta nasib para pencari keadilan yang belum jelas dari pengadilan (Anggraeni, 2020; Joharudin, Septiadi, Maharani, Aisi, \& Nurwahyuningsih, 2020).

Konsep penegakan hukum di Indonesia merupakan serangkaian dari proses mengimplementasikan gagasan dan tujuan hukum yang memuat struktur nilai yang di dalamnya mengandung rasa keadilan serta kebenaran yang hakiki, dalam pelaksanaanya tentu memerlukan instrumen penegakkan hukum seperti lembaga kepolisian, kejaksaaan, serta lembaga pengadilan sebagai salahsatu unsur yang telah menjadi doktrin dalam sistem hukum indonesia, dan bisa dikatakan bahwa inti dari penegakan hukum adalah supremasi nilai yang di dalamnya mengandung rasa keadilan (Rahardjo, 2009). Secara konsepsi umum, maksud dari penegakan hukum yaitu bentuk dari pengejawantahan nilai dari hasil penjabaran kaidah-kaidah dan sikap untuk membentuk, menjaga, serta memelihara kedamaian dalam lingkungan, oleh karenanya tidak bisa dikatakan bahwa dalam penegakan hukum hanya sebatas pelaksanaan peraturan perundang-undangan saja (Husein Maruapey, 2017).

Dilihat dari beberapa penelitian sebelumnya yaitu Adlin \& Yusri (2020) mengenai penegakan hukum pemerintahan di pekanbaru terhadapat covid-19 yang menghasilkan penyebab surat edaran ini sulit dipaksakan berlakunya karena edaran walikota ini tidak memuat sanksi bagi pelanggarnya, 
rendahnya tingkat kesadaran hukum masyarakat dan politik pemerintah pusat. Hidayat (2020) mengenai Angkah -Langkah Strategis Untuk Mencegah Pandemi Covid-19 Di Lembaga Pemasyarkatan Indonesia menghasilkan bahwa Kementrian Hukum dan Ham telah melakukan langkah-langkah pencegahan Covid19 di Lembaga Pemasyarakatan melalui keputusan Menteri dan penelitian oleh Syamsiah (2020) Penyelesaian Perjanjian Hutang Piutang Sebagai Akibat Forje Majeur Karena Pandemic Covid 19 yang menghasilkan Keadaan atau peristiwa tersebut tidak dapat dipertanggung jawabkan kepada debitur, sehinnga si debitur tersebut tidak dalam keadaan beritikad buruk. Dari beberapa penelitian terdahulu belum ada yang khusus melihat bagaimana keadilan untuk pencari keadilan, disini penulis melihat dari sudut pandang berbeda dari lainnya yaitu melihat bagaimana kondisi pandemic covid-19 pada pengeakan hukum dari fenomena pencari keadilan.

Dalam hal kaitannya dengan penegakan hukum di Lembaga pengadilan dalam keadaan pandemi ini, Mahkamah Agung harus melakukan inovasi serta penyesuaian, paling tidak harus dapat menutup tiga persoalan klasik yang selama ini menjadi permasalahan para pencari keadilan, yaitu persoalan keterlambatan (delay), persoalan akses atau keterjangkauan (acess to justice), dan persoalan integritas (integrity) (Rifqi, 2020). Dalam rangka membenahi masalah tersebut, Mahkmah Agung harus melakukan perubahan dan Inovasi di bidang administrasi serta teknis peradilan, sehingga masyarakat yang sedang dihadapkan dengan permasalahan hukum akan tetap mendapatkan pemenuhan hak-haknya serta mendapatkan kepastian hukum, meskipun sedang dihadapkan dengan krisis kesehatan.

\section{METODOLOGI PENELITIAN}

Metode untuk membahas penelitian ini, yaitu dengan mengunakan pendekatan yuridis normatif, yakni menjelaskan dan memberikan gambaran mengenai faktor-faktor penegakan hukum di pengadilan dalam keadaan pandemi. Analisis pembahasannya yaitu dengan studi kepustakaan (library research) terhadap peraturan-peraturan hukum dan karya ilmiah lainnya yang dikaji untuk memberikan penjelasan ilmiah yang sesuai dengan topik pembahasan serta menggunakan pendekatan kualitatif (Sugiyono, 2013)

\section{HASIL DAN PEMBAHASAN}

Dalam Kamus Besar Bahasa Indonesia (KBBI), penegak mempunyai arti “orang yang menegakan atau mendirikan, Sedangkan makna dari Penegak hukum adalah seseorang atau lebih yang menegakkan hukum, dalam doktrin hukum di Indonesia berarti advokat atau pengacara, hakim, jaksa, serta polisi. Menurut Satjipto Raharjo penegakan hukum adalah sebuah konsep normatif, yang mana di dalamnya setiap elemen masyarakat hanya tinggal menerapkan apa yang termaktub di dalam undang-undang (Rahardjo, 2009). Menurut Bardan Nawawi terpetik dari bukunya Didik S, pada hakikatnya penegakan hukum adalah konsepsi mengenai perlindungan atas hak asasi manusia, dan tegaknya keadilan serta inegritas, serta tidak adanya kesemana-menaan atas kekuasaan serta adanya praktek memberikan perlakuan istimewa atau bahkan tidak adil terhadap seseorang atau kelompok (favoritism) yang mana hal tersebut telah diwujudkan dalam seluruh aturan atau norma yang telah berada dalam tatanan hidup masyarakat (Suparman, 2016).

Pada sistem hukum di indonesia lahirnya penegakan hukum ditujukan agar ketertiban dapat ditingkatkan serta untuk mendapatkan kepastian hukum bagi masyarakat para pencari keadilan, Hal tersebut dapat dilakukan setidaknya dengan menjalankan tugas pokok beserta fungsi masing-masing lembaga penegakan hukum yang sesuai dengan proporsi yang didasarkan atas sinergitas dari lembaga terkait. 
Dalam tatanan sosial di Indonesia, terdapat masyarakat yang multikultural, yang mana tingkat perkembangannya berbeda, hal tersebut dapat berpengaruh terhadap pola penegakan norma itu sendiri, karena dalam tatanan masyarakat yang modern, orang-orang lebih rasional serta tiap individu memiliki tingkat diferensiasi serta spesialisasi yang tinggi, oleh karenanya pengorganisasian penegakan hukumnyapun sangat birokratis dan semakin kompleks (Arliman, 2019).

Doktrin yang berkembang di Indonesia, bahwa elemen penegakan hukum adalah advokat atau pengacara, hakim, jaksa serta kepolisian, namun diluar institusi tersebut masih ada institusi lain, diantaranya Direktorat Jendral Pajak, Direktorat Jendral Bea Cukai, serta Direktorat Jendral Imigrasi (Juwana, 2005). Secara teoritis pembahasan mengenai penegakan hukum di Indonesia akan dikatakan efektif apabila 5 (lima) faktor ini dapat terpenuhi, yaitu: (1) faktor mengenai instrumen hukum (peraturan), (2) faktor dari aparat penegak hukumnya, (3) faktor tersedianya sarana dan fasilitas, (4) faktor sosial masyarakat, (5) faktor kebudayaan. Artinya, acces to justice para pencari keadilan pada institusi pengadilan setidaknya dalam kondisi pandemi ini, ke lima elemen tersebut harus berjalan dengan baik.

\section{Faktor Instrumen Hukum}

Secara konkret, pelaksanaan penyelenggaraan hukum pada tatanan masyarakat seringkali dihadapkan dengan pertentangan antara kepastian hukum dengan rasa keadilan, suatu kebijakan atau keputusan yang tidak berlandaskan kepada ketentuan hukum memang dibenarkan, selama tidak bertentangan dengan ketentuan yang berlaku. Namun bagaimana jika penyelenggaran hukum tersebut dihadapkan dengan kondisi darurat, dalam kondisi ini adanya wabah pandemi covid-19, dimana yang menjadi pertentangan adalah antara kepastian hukum dengan keselamatan warga negara.

Namun, masalah mulai muncul ketika Presiden Jokowi terbitkan Peraturan Pemerintah Nomor 21 Tahun 2020 yang mengatur pemberlakuan Pembatasan Sosial Berskala Besar (PSBB), dimana pemenuhan hak-hak terhadap para pencari keadilan menjadi terhambat, karena apabila persidangan tetap dilaksanakan seperti biasa akan sangat beresiko terhadap penyebaran Covid-19, sedangkan apabila persidangan ditunda akan mengakibatkan kerugian terhadap hak para pencari keadilan. Tidak hanya itu, jumlah perkara yang diterima oleh suatu pengadilan seperti di Pengadilan Agama dalam kurun waktu 5 (lima) tahun terakhir (2012-2016) terus meningkat (Ramdani Wahyu, 2017), tentu hal tersebut menjadi pekerjaan besar Mahkamah Agung, sehingga perlu pendekatan serta penanganan yang sitematis dan bertahap, agar tidak terjadi penumpukan perkara serta terhalangnya hak-hak masyarakat pencari keadilan, terlebih pada prinsipnya pengadilan dilarang untuk menolak penerimaan perkara (UU No. 48 Tahun 2009 tentang kekuasaan kehakiman).

Dalam menyikap hal tersebut, Mahkamah Agung harus membuka kembali produk hukum yang sebelumnya pernah dikeluarkan, yaitu Peraturan Mahkamah Agung (PERMA) Nomor 1 Tahun 2019 tentang Administrasi Perkara Pengadilan Secara Elektronik. Lahirnya PERMA ini merupakan upaya Mahkamah Agung untuk mewujudkan pelayanan pengadilan yang modern, dan hal tersebut sesuai dengan apa yang telah termaktub dalam cetak biru pembaharuan peradilan tahun 2010-2035 yaitu salahsatu bentuk usaha dalam upaya mengelola institusi peradilan dengan lebih baik, dengan harapan agar tumbuh kepercayaan pada masyarakat dan terpenuhinya kebutuhan serta hak-hak para pencari keadilan (Mahkamah Agung, 2010).

PERMA ini sangat tepat untuk di implementasikan dalam kondisi adanya pandemi ini, karena proses berperkara di pengadilan bisa dilakukan secara elektronik (e-court), serta proses administrasi dan persidangan bisa tercover dengan aplikasi ini, dimulai dari proses pendaftaran perkara atau dikenal 
dengan istilah (e-filling), kemudian proses pembayaran perkara atau dikenal dengan istilah (e-payment), serta proses pemanggilan para pihak atau dikenal dengan istilah (e-summon), serta dalam proses persidanganpun bisa dilakukan secara elektronik atau biasa dikenal dengan istilah (e-litigasi), hal tersebut juga dikuatkan dengan keluarnya Surat Edaran Mahkamah Agung Nomor No 1 Tahun 2020, Surat Edaran Nomor 3 Tahun 2020 tentang Pedoman Pelaksanaan Tugas Selama Masa Pencegahan Penyebaran Corona Virus Disease 2019 (Covid-19) di Lingkungan Mahkamah Agung dan Badan Peradilan di Bawahnya, yang mana Surat Edaran tersebut berpedoman pada Surat Edaran Menteri Pendayagunaan Aparatur negara dan Reformasi Birokrasi Nomor 19 Tahun 2020 yang bersisi tentang penyesuaian Sistem Kerja Aparatur Sipil Negara dalam Upaya Pencegahan Penyebaran Covid-19 di Instansi Pemerintah.

Dalam PERMA tersebut, secara Teknik proses administrasi serta persidangan secara elektronik bisa dilakukan oleh Pengacara serta masyarakat yang telah terdaftar dan terverifikasi sebelumnya. Administrasi perkara secara elektronik ini meliputi seluruh proses administrasi dalam persidangan, dimulai dari penerimaan surat gugatan atau permohonan, proses jawab menjawab, proses melakukan bantahan atau perlawanan, proses memberikan kesimpulan, proses pembayaran, proses penyampaian serta pengelolaan dokumen-dokumen perkara, seperti pada perkara Perdata, Perdata Agama, PTUN, serta pada perkara di Pengadilan Militer

Penerapan PERMA No 1 Tahun 2019 telah menjadi dasar hukum dilaksanakannya adminisrasi perkara secara elektronik, dan seyogyanya harus dimaksimalkan, karena proses administrasi serta pelaksanaan persidangan dapat dilakukan secara efektif dan efesien, bahkan dengan adanya PERMA ini memungkikan menggelar persidangan secara teleconference terutama dilingkungan Pengadilan Negeri, Kejaksaan, atau Rumah Tahanan.

\section{Faktor Para Penegak Hukum}

Penegakan hukum pada tatanan masyarakat, selain tergantung pada aturan yang telah ada sebelumnya juga akan sangat ditentukan oleh aparat penegak hukumnya. Aparat penegak hukum harus menjalankan tugas dan fungsinya sesuai dengan ketentuan undang-undang yang berlaku, agar penegakan hukum dapat berjalan dengan baik, terlebih lagi jika terdapat oknum penegak hukum yang tidak menjalankan fungsinya, maka hal tersebut dapat menurunkan citra institusi, dan tentunya hal tersebut merupakan contoh tidak baik terlebih jika terjadi pada institusi pengadilan.

Pengadilan sebagai institusi penegak hukum dalam menjalankan tugasnya tidak bisa lepas dari peraturan atau hukum yang telah tertuang dalam undang-undang. Peran Lembaga peradilan dalam upaya untuk mewujudkan pengadilan yang mandiri, efektif dan efisien belum sepenuhnya berjalan dengan baik. Kesiapan para penegak hukum dalam menghadapi era digitalisasi harus dibarengi dengan meningkatnya kemampuan penyesuaian para penegak hukum, terlebih dimasa pandemi ini para penegak hukum harus bekerja keras, karena sejalan dengan Penerapan PERMA No 1 Tahun 2019 telah menjadi dasar hukum untuk pelaksanaan adminisrasi perkara secara elektronik, terlebih setelah dikeluarnya Surat Edaran Mahkamah Agung Nomor 1 Tahun 2020, Surat Edaran Nomor 3 Tahun 2020 mutlak harus dilakukan, agar persidangan dapat tetap berjalan dengan menetapkan skala prioritas penanganan perkara.

Tidak hanya berbicara mengenai hal prinsipil yang melekat pada penegak hukum, dalam kondisi pandemi ini juga mengaharuskan para penegak hukum harus menguasai sistem digitalisasi pengadilan dalam pelaksanaan kerja serta berkomunikasi, sedangkan kendala utama adalah berbedanya tingkat pemahaman serta kemampuan aparat pengadilan, terkhusus bagi hakim serta tenaga teknis lainnya, sehingga perlu adanya percepatan pelatihan tekait penggunaan digitalisasi sistem ini. 


\section{Sarana serta Fasilitas Pendukung}

Dalam rangka melaksanakan fungsi teknis lembaga peradilan, integritas serta kemandirian merupakan modal utama untuk mendapatkan kepercayaan publik. Tentu disamping kepastian hukum serta kualitas putusan yang mana hal tersebut merupakan core bussines peradilan. Dalam pelaksanaan fungsi pengadilan yang mana di dalamnya termasuk penguatan sarana dan fasilitas yang mendukung, adalah syarat mutlak agar pelayanan kepada masyarat bisa dilakukan dengan lebih optimal.

Dua misi penting yang telah tercanang dalam cetak biru peradilan 2010-2035, yaitu (1) Dapat memberikan advis hukum yang optimal serta berkepastian hukum bagi masyarakat pencari keadilan (2) Meningkatkan kepercayaan publik serta transparansi institusi pengadilan (Mahkamah Agung, 2010), tuntutan modernisasi peradilan serta handalnya teknologi informasi dalam memberikan pelayanan yang efektif dan efisien menjadi alasan bagi Mahkamah Agung mengeluarkan PERMA No 1 Tahun 2019, dan ini menjadi program prioritas dari Mahkamah Agung dalam rangka menyambut era digitalisasi 4.0 yang terpadu. Bahkan pemerintah telah menggelontorkan anggaran tambahan kepada Mahkamah Agung untuk mendukung program tersebut dengan anggaran sebesar Rp. 413.000.000.000 (empat ratus tiga belas miliar rupiah) yang mana anggaran tersebut dikucurkan lewat Bagian Anggaran Bendahara Umum Negara (BA BUN) (Nofriandi, 2020). Adanya penambahan anggaran tersebut akan diperuntukan untuk penunjang sarana dan prasarana serta memastikan kesiapan satuan kerja pengadilan dalam penerapan aplikasi elektronik ini, bahkan Mahkamah Agung telah mengalokasikan anggaran sebesar 70\% dari total anggaran atau sekitar Rp. 293.000.000.000 (dua ratus sembilan puluh tiga miliar rupiah) untuk mendukung program ini (Nofriandi, 2020).

Dengan melihat keseriusan pemerintah dalam menghadapi era digitalisasi di lingkungan peradilan ini, seharusnya sarana dan prasarana sudah tidak menjadi permasalahan, terlebih ketika dihadapkan dengan kondisi pandemi ini, karena perencanaan anggaran serta penambahan anggaran dari pemerintah sendiri mulai efektif per tanggal 01 Juni 2019 (Nofriandi, 2020). Semakin besar alokasi yang disediakan untuk anggaran komputerisasi pengadilan (court computerization), maka proses persidangan akan semakin cepat. Investasi ini mendorong produktifitas hakim yang terukur dari jumlah kasus yang dapat diselesaikan (Ramdani Wahyu, 2018).

Penyesuaian sistem administrasi di institusi pengadilan ini harus dibarengi dengan standar fasilitas yang mendukung, dengan adanya pandemi ini pengadilan harus dapat memaksimalkan sarana dan prasarana yang telah tersedia, seperti dengan pemberian informasi persidangan dengan daring atau dengan menggunakan telpon, memaksimalkan informasi pada media sosial serta website, memaksimalkan adanya call center pengadilan, mengarahka semua layanan dengan menggunakan ecourt. Dengan memaksimalkan sarana dan fasilitas ini akan dapat membantu masyarakat untuk mendapatkan informasi yang dibutuhkan.

\section{Faktor Sosial Masyarakat}

Pada dasarnya setiap elemen masyarakat atau kelompok berperan penting dalam membangun penegakan hukum yang optimal. Persoalan yang seringkali muncul adalah taraf dari kepatuhan serta kesadaran hukum masyarakat yang berbeda. Adanya nilai derajat dari kepatuhan serta kesadaran hukum masyarakat menjadi indikator penting berfungsinya hukum. Semakin baik tingkat pemahaman serta kesadaran hukum masyarakat, maka akan semakin baik juga penegakan hukum tersebut, sebaliknya semakin rendahnya tingkat pemahaman serta kesadaran hukum masyarakat, maka penegakan hukumpun akan semakin sulit. Kesadaran hukum tersebut diantaranya meliputi tentang pengetahuan hukum, ketaatan terhadap hukum, serta penghayatan terhadap fungsi-fungsi hukum. 
Dari sudut sosial, masyarakat Indonesia digolongkan menjadi masyarakat yang majemuk serta multkultural. Seorang penegak hukum harus dapat melihat perbedaan masyarakat beserta tatanan status atau kedudukan yang tumbuh di dalam masyarakat. Tidak hanya itu, dalam penegakan hukum, sangat dipengaruhi oleh kondisi serta keadaan sosial masyarakat. Masyarakat yang tumbuh dan hidup dibawah penegakan hukum yang otoriter, maka akan memposisikan penerapan norma hukum yang berbeda dengan keadaan masyarakat yang tumbuh dan hidup dalam penegakan hukum yang terbuka atau egaliter. Artinya, penegakan hukum yang hakiki tidak hanya semata-mata ditentukan oleh penegak hukumnya, melainkan akan ditentukan oleh kehendak serta partisipasi masyakarat di dalamnya.

Dalam kondisi pandemi ini tentu perlu adanya nalar yang baik dari masyarakat, serta peran pemerintah dalam memberikan edukasi juga harus dimaksimakan, karena tidak hanya kepastian hukum yang menjadi tujuan, namun keselamatan serta keberlangsungan hidup warga negara juga harus dijaga. Oleh karenanya pengaturan mengenai standar protokol covid-19 dalam menjalani proses penegakan hukum di pengadilan harus disampaikan dan dijalankan dengan baik.

\section{Faktor Kebudayaan}

Peran dari kebudayaan sangat besar untuk tatanan hidup masyarakat baik secara perorangan ataupun kelompok, yaitu untuk mengatur bagaimana manusia dapat berhubungan dengan sekitarnya, yang mana fugsinya agar manusia lebih faham serta mengerti bagaimana seharusnya melakukan suatu perbuatan, melakukan sebuah tindakan, serta menentukan sikap pada lingkungan sosial (Soekanto, 2011). Kebudayaan adalah sebuah abstraksi dari suatu nilai yang melekat pada norma, nilai-nilai yang mencakup konsepsi mengenai hal yang dianggap patut dan baik sehingga diikuti oleh masyarakat, serta nilai mana yang dianggap tidak baik sehingga dihindari dan tidak di indahkan oleh masyarakat. Budaya kompromitis seringkali menjadi problem, karena di dalam kebudayaan yang menjadi faktor utama adalah nilai, sehingga tingkat kepatuhan masyarakat terhadap aturan atau norma masih rendah.

Para penegak hukum dalam menghadapi pandemi ini tentu harus melihat faktor sosial budaya, dalam penanganan wabah ini tidak cukup hanya melibatan aspek dari medis saja, karena antara wabah penyakit dengan aspek masyarakat serta budaya adalah dua mata koin yang tidak dapat terpisah (Febby Febiandi, 2020) satu sisi, penyakit akan mudah menyebar karena budaya tertentu dalam masyarakat, atau setidaknya cara-cara hidup masyarakat menjadi faktor penyebabnya. Oleh karenanya, hal tersebut menjadi salahsatu dasar pertimbangan diberlakukannya Pembatasan Sosial Berskala Besar (PSBB).

Sesuai dengan SEMA No. 1 Tahun 2020, maka perlu dilakukannya penyesuaian sitem kerja, yang mana hal tersebut merupakan bentuk penyesuaian serta diharapkan dapat mengurangi penyebaran dari covid-19 di masyarakat, yang mana diantaranya:

1. Penyesuaian sistem kerja hakim dan aparatur pengadilan dengan menjalankan tugas kedinasan di rumah (work from home)

2. Pemanfaatan aplikasi e-court pelaksanaan pelaksanaan persidangan dengan e-litigasi

3. Mengatur sistem pelaksanaan tugas agar layanan masyarakat tidak terhambat

4. Pemberlakuan social distancing dan menggunakan alat pelindung (masker, sarung tangan medis) ketika mendapat giliran bekerja

5. Menyidiakan hand sanitizer dan alat pendeteksi suhu badan di setiap satuan kerja

6. Pembatasan pelaksanaan tugas kedinasan bagi hakim dan aparatur peradilan

Dalam penegakan hukum, tentu dalam realitasnya kelima faktor tersebut akan saling berkesinambungan dan mempunyai kaitan yang erat, hal tersebut dikarenakan dalam penegakan hukum masing-masing faktor tersebut akan saling mempengaruhi. Kurang maksimalnya penegakan dalam 
menjalankan satu faktor akan berdampak terhadap yang lainnya, karena keseluruhannya menjadi faktor utama dan penting dalam penegakannya, terutama ketika dihadapkan dengan kondisi pandemi ini.

\section{SIMPULAN}

Kondisi penyebaran covid-19 di Indonesia sudah sangat memprihatinkan, dan kondisi ini berdampak sangat besar terhadap penegakan hukum di institusi pengadilan. Dalam kondisi pandemi ini institusi pengadilan harus tetap berjalan, agar pemenuhan hak-hak para pencari keadilan dapat terpenuhi. Dalam upaya penegakan hukum di pengadilan dalam keadaan pandemi covid-19 ini setidaknya harus memenuhi 5 (lima) faktor: (1) Faktor Hukum, (2) Faktor Penegak Hukum, (3) Faktor Sarana dan Fasilitas Pendukung, (4) Faktor Sosial Masyarakat, dan (5) Faktor Kebudayaan. Serta dalam penegakan hukum di institusi pengadilan ini harus tetap menegakan standar protokol covid-19, agar tingkat penyebaran serta keselamatan para pencari keadilan tetap terjaga.

\section{DAFTAR PUSTAKA}

Adlin, A., \& Yusri, A. (2020). Penegakan Hukum Pemerintahan: Kekuasaan Walikota Pekanbaru Memberlakukan Beleidsregels Guna Memutus Penyebaran Virus Covid-19 di Kota Pekanbaru. Jurnal Ilmiah Muqoddimah: Jurnal Ilmu Sosial, Politik Dan Hummanioramaniora, $4(2), 71-81$.

Anggraeni, R. R. D. (2020). Wabah Pandemi Covid-19, Urgensi Pelaksanaan Sidang Secara Elektronik. 'ADALAH, 4(1).

Arliman, L. (2019). Surat Dakwaan dalam Hukum Acara Pidana Sebagai Bentuk Mendukung Penegakan Hukum di Indonesia. Kosmik Hukum, 19(1).

Danu, D. (2020). Penjelasan soal Darurat Sipil yang Akan Diambil Jokowi untuk Lawan Corona. Retrieved May 13, 2020, from Detik.com website: https://news.detik.com/berita/d4958409/penjelasan-soal-darurat-sipil-yang-akan-diambil-jokowi-untuk-lawan-corona.

Gugus Tugas Percepatan Penangana COVID-19. (2020). Gugus Tugas Percepatan Penanganan Covid-19.

Handayanto, R. T., \& Herlawati, H. (2020). Efektifitas Pembatasan Sosial Berskala Besar (PSBB) di Kota Bekasi Dalam Mengatasi COVID-19 dengan Model Susceptible-Infected-Recovered (SIR). Jurnal Kajian Ilmiah, 20(2), 119-124.

Hidayat, R. H. (2020). Langkah-Langkah Strategis untuk Mencegah Pandemi Covid-19 di Lembaga Pemasyarkatan Indonesia. Jurnal Pendidikan Kesehatan, 9(1), 43-55.

Husein Maruapey, M. (2017). PENEGAKAN HUKUM DAN PERLINDUNGAN NEGARA (Analisys Kritis Terhadap Kasus Penistaan Agama Oleh Patahana Gubernur DKI Jakarta). JIPSI-Jurnal Ilmu Politik Dan Komunikasi UNIKOM, 7.

Joharudin, A., Septiadi, M. A., Maharani, S., Aisi, T. D., \& Nurwahyuningsih, N. (2020). PANIC SYNDROM COVID-19: PENEKANAN TERHADAP KEBIJAKAN YANG DIBERIKAN. Jurnal Perspektif, 4(1), 44-53.

Juwana, H. (2005). Penegakan Hukum dalam Kajian Law and Development: Problem dan Fundamen bagi Solusi di Indonesia. Indonesian J. Int'l L., 3, 212.

Mahkamah Agung, R. I. (2010). Cetak biru pembaruan peradilan 2010-2035. Jakarta: Mahkamah Agung RI.

Nofriandi, P. (2020). PEROLEH TAMBAHAN ANGGARAN LEWAT BA BUN, MA PRIORITASKAN IMPLEMENTASI E-COURT DAN PERUMAHAN HAKIM. Retrieved May 20, 2020, from Mahkamah Agung website: https://www.mahkamahagung.go.id/id/berita/3567/perolehtambahan-anggaran-lewat-ba-bun-ma-prioritaskan-implementasi-e-court-danperumahan-hakim 


\section{Khazanah Hukum, Vol. 2 No. 2: 56-64}

JUSTICIABELEN: Penegakan Hukum di Institusi Pengadilan dalam menghadapi Pandemi Covid-19 Azis Ahmad Sodik

Rahardjo, S. (2009). Hukum dan Perilaku: hidup baik adalah dasar hukum yang baik. Penerbit Buku Kompas.

Ramdani Wahyu, S. (2018). Darurat Perceraian dalam Keluarga Muslim Indonesia. Lembaga Penelitian dan Pengabdian kepada Masyarakat.

Rifqi, M. J. (2020). Perkembangan dan Pemanfaatan Teknologi Informasi Pengadilan Agama. Jurnal Al-Qadau: Peradilan Dan Hukum Keluarga Islam, 7(1), 70-83.

Soekanto, S. (2011). Faktor-Faktor yang Mempengaruhi Penegakan Hukum (Cet. Ke-10). Jakarta: PT Raja GrafindoPersada.

Sugiyono. (2013). Memahami Penelitian Kualitatif. Bandung: CV. Alfabeta.

Suparman, H. A. (2016). Penegakan Hukum terhadap penyelenggaraan pelayanan publik. Jurnal Wawasan Yuridika, 31(2), 177-182.

Syamsiah, D. (2020). PENYELESAIAN PERJANJIAN HUTANG PIUTANG SEBAGAI AKIBAT FORJE MAJEUR KARENA PANDEMIC COVID 19. Legal Standing: Jurnal Ilmu Hukum, 4(1), 306-313. 